\title{
KOMPATIBILITAS CENDAWAN METARHIZIUM ANISOPLIAE (METSCHN.) SOROKIN DENGAN NEMATODA ENTOMOPATOGEN STEINERNEMA SP.
}

\author{
Imron Rosyidi, Hari Purnomo, Nanang Tri Haryadi, \& Mohammad Hoesain \\ Program Studi Agroteknologi, Fakultas Pertanian, Universitas Jember \\ Jl. Kalimantan 37, Kampus Tegal Boto, Jember 68121 \\ E-mail: haripurnomo.faperta@unej.ac.id
}

\begin{abstract}
Compatibility Metarhizium anisopliae (Metschn.) Sorokin with entomopathogenic nematode Steinernema sp. Metarhizium anisopliae (Metschn.) Sorokin and entomopathogenic nematode Steinernema sp. can be used as biological control of insect pests. The objective of this research was to identify compatibility between fungus $M$. anisopliae with entomopathogenic nematode Steinernema sp. This research was conducted using a completely randomized design (CRD) consisting of 5 treatments and repeated 5 times. The treatment used was M. anisopliae isolates Jombang 1 with Steinernema sp. (M1), M. anisopliae Jombang 2 with Steinernema sp. (M2), M. anisopliae isolates Kediri with Steinernema sp. (M3), M. anisopliae isolates Bondowoso with Steinernema sp. (M4), and M. anisopliae isolates Banyuwangi with Steinernema sp. (M5). Based on this research result, compatibility between the fungus $M$. anisopliae with entomopathogenic nematode Steinernema sp. was antagonistic. This occurs due to the symbiotic bacteria Xenorhabdus sp. that produced compounds antimycotic and capable to inhibit the growth of fungus $M$. anisopliae.
\end{abstract}

Key words: compatibility, M. anisopliae, Steinernema sp., Xenorhabdus sp.

\begin{abstract}
ABSTRAK
Kompatibilitas cendawan Metarhizium anisopliae (Metschn.) Sorokin dengan nematoda entomopatogen Steinernema sp. Metarhizium anisopliae (Metschn.) Sorokin dan nematoda patogen serangga Steinernema sp. dapat digunakan sebagai agens pengendali hayati serangga hama. Penelitian ini bertujuan untuk mengetahui kompatibilitas antara cendawan $M$. anisopliae dengan Steinernema sp. Penelitian ini menggunakan Rancangan Acak Lengkap lima perlakuan dan lima ulangan. Perlakuan yang digunakan yaitu M. anisopliae isolat Jombang 1 dengan Steinernema sp. (M1), M. anisopliae Jombang 2 dengan Steinernema sp. (M2), M. anisopliae isolat Kediri dengan Steinernema sp. (M3), M. anisopliae isolat Bondowoso dengan Steinernema sp. (M4), dan M. anisopliae isolat Banyuwangi dengan Steinernema sp. (M5). Hasil penelitian menunjukkan kompatibilitas antara cendawan M. anisopliae dengan nematoda Steinernema sp. bersifat antagonis. Hal ini terjadi dikarenakan adanya bakteri simbion Xenorhabdus sp. yang menghasilkan senyawa antimikotik dan mampu menghambat pertumbuhan cendawan $M$. anisopliae.
\end{abstract}

Kata kunci: kompatibilitas, M. anisopliae, Steinernema sp., Xenorhabdus sp.

\section{PENDAHULUAN}

Aplikasi kombinasi agens pengendali hayati $(\mathrm{APH})$ ditujukan untuk meningkatkan efektivitas pengendalian, dan sebagai upaya untuk mengurangi penggunaan pestisida dengan ditemukannya metode pengendalian yang lebih ekonomis dan efisien $(\mathrm{Xu}$ et al., 2011). Ansari et al. (2008) mengombinasikan Metarhizium anisopliae dengan Steinernema sp. dalam mengendalikan hama Otiorhynchus sulcatus dengan memberikan mortalitas lebih dari $93 \%$ pada uji skala laboratorium dan lebih dari $83 \%$ pada uji skala lapang.
Hartati (2013) menyebutkan bahwa penggunaan APH seperti cendawan entomopatogen M. anisopliae dan nematoda entomopatogen Steinernema sp. banyak dilakukan untuk mengendalikan uret Lepidiota stigma pada tanaman tebu. Penelitian sebelumnya yang dilakukan oleh Alfarizi (2014) mengenai pengendalian uret menggunakan nematoda entomopatogen Steinernema sp. dengan cendawan entomopatogen $M$. anisopliae di laboratorium, menunjukkan perlakuan aplikasi kombinasi Steinernema sp. dengan $M$. anisopliae memberikan mortalitas uret sebesar $92 \%$ pada pengamatan tiga minggu setelah aplikasi kombinasi Steinernema sp. terlebih dahulu dan 48 jam berikutnya 
aplikasi $M$. anisopliae, sedangkan padapengamatan tiga minggu setelah aplikasi kombinasi $M$. anisopliae terlebih dahulu dan 48 jam berikutnya aplikasi Steinernema sp. memberikan mortalitas uret sebesar $84 \%$.

Menurut Alfarizi (2014), gejala kematian uret yang ditunjukkan pada perlakuan kombinasi Steinernema sp. dengan $M$. anisopliae sama dengan gejala kematian uret yang disebabkan oleh aplikasi Steinernema sp. secara tunggal dan tidak ditemukan pertumbuhan miselia M. anisopliae pada tubuh uret yang mati pada perlakuan kombinasi Steinernema sp. dengan M. anisopliae. Oleh karena itu pada penelitian ini dilakukan kombinasi cendawan entomopatogen $M$. anisopliae dengan nematoda entomopatogen Steinernema sp. untuk mengetahui kompatibilitas antara cendawan entomopatogen $M$. anisopliae dan nematoda entomopatogen Steinernema sp.

\section{METODE PENELITIAN}

Tempat dan Waktu. Penelitian dilaksanakan di Laboratorium Agroteknologi, Fakultas Pertanian, Universitas Jember pada bulan Januari sampai Agustus 2016.

Peremajaan Isolat $M$. anisopliae. Peremajaan dilakukan pada media PDA (Potato Dextrose Agar). Secara aseptis koloni cenda wan diambil dan digoreskan secara strike plate pada media PDA dan diinkubasi pada ruang gelap dengan suhu rata-rata $28{ }^{\circ} \mathrm{C}$ selama kurang lebih 15 hari sampai cendawan entomopatogen $M$. anisopliae tumbuh memenuhi media. Isolat cendawan $M$. anisopliae yang digunakan yaitu isolat Jombang 1, Jombang 2, Kediri, Banyuwangi dan Bondowoso. Semua isolat $M$. anisopliae diisolasi dari serangga inang Lepidiota stigma.

\section{Penyediaan Suspensi Nematoda Entomopatogen} Steinernema sp. Nematoda entomopatogen Steinernema sp. diperbanyak dengan carain vivo menggunakan metode perangkap White (White trap) kemudian diinkubasi selama 7-15 hari. Tenebrio molitor yang mati terinfeksi Steinernema sp. dipanen dan populasi nematoda entomopatogen dihitung pada Mikroskop (Olympus SZ51, Tokyo Jepang) dalam Countingdish.

Pembuatan Media NBTA (Nutrient Bromothymol Blue Agar). Sebanyak $23 \mathrm{~g}$ NA Nutrient Agar (Difro ${ }^{\mathrm{TM}}$ Becton Dickinson and Company, USA) dan 0,025 g Bromothymol Blue (ACS Merck, German) dicampur dengan1 L air destilasi steril, dan dimasak 30 menit lalu diautoklaf (Wisd Daihan, Korea) 15 menit suhu $121{ }^{\circ} \mathrm{C}$ bertekanan $1 \mathrm{~atm}$, setelah steril didiamkan sampai dingin dan ditambahkan 0,04 g TTC (Triphenyl Tetrazolium Chloride) (Sigma- Aldrich, Austria USA) yang sudah disterilisasi menggunakan microdisk (Kurabo, Cina).

Isolasi Bakteri Simbion Xenorhabdus sp. Bakteri simbion Xenorhabdus sp. diisolasi dari larva T. molitor terinfeksi Steinernema sp.. Larva terinfeksi disterilisasi permukaan dengan dicelupkan pada alkohol $70 \%$ selama 10-15 detik, dibilas tiga kali dengan air destilasi steril, dan dikeringkan pada kertas saring (Whatman, UK). Tungkai T. molitor mati dipotong dan cairan haemolympha yang keluar dari tungkai digoreskan pada media NBTA, selanjutnya diinkubasi pada ruang gelap suhu rata-rata $28{ }^{\circ} \mathrm{C}$ selama 24 jam sampai terdapat koloni bakteri simbion Xenorhabdus sp. fase primer yang tumbuh dengan tanda warna koloni biru.

Uji Kompatibilitas secara Bioassay. Uji kompatibilitas M. anisopliae dengan Steinernema sp. pada larva $T$. molitor dilakukan dengan dua uji bioassay. Setiap uji bioassay terdapat lima perlakuan yang diulang lima kali diantaranya $M$. anisopliae Jombang 1 (M1) dengan Steinernema sp., M. anisopliae Jombang 2 (M2) dengan Steinernema sp., M. anisopliae Kediri (M3) dengan Steinernema sp., M. anisopliae Banyuwangi (M4) dengan Steinernema sp. dan M. anisopliae (M5) dengan Steinernema sp.

Pada bioassay pertama T. molitor $(\mathrm{n}=10$ ekor) dicelupkan pada suspensi $M$. anisopliae $\left(10^{8} \mathrm{spora} / \mathrm{ml}\right)$ selama 10 detik. Selanjutnya diinkubasi selama 48 jam pada cawan Petri (Anumbra, Ceko) yang berisi kertas saring (Whatman TM, UK) dan kapas basah untuk mengatur kelembapan. Pada periode 48 jam berikutnya, T. molitor ( $\mathrm{n}=10$ ekor) diinfeksi dengan $1 \mathrm{ml}$ suspensi Steinernema sp. per cawan Petri ( \pm 200 Juvenil infektif), setelah itu diinkubasi pada ruangan gelap dengan ratarata suhu ruang $28^{\circ} \mathrm{C}$ sampai $T$. molitor mati terinfeksi, dengan gejala terinfeksi oleh $M$. anisopliae atau Steinernema sp. secara tunggal ataupun oleh keduanya.

Pada bioassay kedua, T. molitor ( $\mathrm{n}=10$ ekor) diinfeksi dengan satu $\mathrm{ml}$ suspensi Steinernema sp. ( \pm 200 Juvenil infektif) dan diinkubasi selama 48 jam. Setelah 48 jam, T. molitor ( $\mathrm{n}=10$ ekor) dicelupkan pada suspensi $M$. anisopliae $\left(10^{8} \mathrm{spora} / \mathrm{ml}\right)$ selama 10 detik, selanjutnya diinkubasi pada ruang gelap dengan suhu ruang $28^{\circ} \mathrm{C}$ sampai serangga uji mati terinfeksi.

Pengamatan dilakukan setiap hari, dimulai dari 1 hari setelah infeksi (HSI) sampai terdapat mortalitas 
serangga mati $100 \%$ pada salah satu perlakuan. Pada pengamatan terakhir semua serangga uji dibongkar dan diamati di bawah mikroskop untuk memastikan serangga mati terinfeksi oleh $M$. anisopliae atau nematoda Steinernema sp.

Interaksi Kompatibilitas Hasil Uji Bioassay. Pengamatan reaksi kompatibilitas pada uji bioassay ditentukan berdasarkan rasio mortalitas kenyataan dengan mortalitas harapan T. molitor yang dihitung setelah terdapat mortalitas $100 \%$ pada salah satu perlakuan. Data mortalitas kenyataan merupakan mortalitas hasil pengamatan langsung, sedangkan mortalitas harapan merupakan nilai mortalitas yang diharapkan berdasarkan respon interaksi. Interaksi kompatibilitas berdasarkan mortalitas T. molitor di tentukan dengan rumus (Farenhorst et al., 2010):

$$
\begin{gathered}
M e=M n+M i\left(1-\frac{M n}{100}\right) \\
X^{2}=\frac{\left(M_{O}-M_{e}\right)^{2}}{M e}
\end{gathered}
$$

dengan:

Mo $=$ Mortalitas kenyataan;

Mi $=$ Mortalitas kontrol infeksi APH pertama secara tunggal;

Mn $=$ Mortalitas kontrol infeksi APH kedua secara tunggal;

Me $=$ Mortalitas harapan .

Jika (Mo-Me) bernilai positif dan nilai X2 > 3,84 maka kombinasi antara $M$. anisopliae dengan Steinernema sp. dikatakan sinergis. Jika (Mo-Me) bernilai negatif dan nilai $\mathrm{X} 2 \leq 3,84$ maka kombinasi antara M. anisopliae dengan Steinernema sp. dikatakan antagonis (Ansari et al., 2008).

Gejala dan Perkembangan Steinernema sp. pada Tubuh T. molitor Mati Terinfeksi. Pengamatan diperoleh dari pengamatan tujuh hari setelah infeksi. Gejala terinfeksi oleh $M$. anisopliae dijelaskan oleh Trizelia at al. (2010) yaitu tubuh larva yang mengeras dan diselimuti oleh hifa cendawan berwarna putih dan kemudian berubah menjadi hijau pucat. Sedangkan gejala serangga terinfeksi Steinernema sp. yaitu perubahan warna pada T. molitor menjadi cokelat muda sampai cokelat gelap (Chaerani et al., 2007). Pengamatan perkembangan Steinernema sp. dalam tubuh T. molitor yang terinfeksi Steinernema sp. dilakukan dengan membedah tubuh T. molitor untuk memastikan terdapat nematoda yang hidup dan berkembang dalam tubuh $T$. molitor yang mati terinfeksi.

Uji Kompatibilitas secara In Vitro. Uji kompatibilitas secara in vitro dilakukan antara $M$. anisopliae dengan bakteri simbion Xenorhabdus sp. pada media NBTA sesuai dengan metode Ansari et al. (2005). Uji kompatibilitas secara in vitro menggunakan lima perlakuan dan diulang lima kali. Kelima perlakuan yaitu M. anisopliae Jombang 1 (M1) dengan Steinernema sp., M. anisopliae Jombang 2 (M2) dengan Steinernema sp., M. anisopliae Kediri (M3) dengan Steinernema sp., M. anisopliae Banyuwangi (M4) dengan Steinernema sp. dan M. anisopliae (M5) dengan Steinernema sp. Potongan subkultur isolat $M$. anisopliae $(\mathrm{D}=0,5 \mathrm{~cm})$ diletakkan pada bagian media NBTA pada jarak $3 \mathrm{~cm}$ dari tepi cawan Petri dan $3 \mathrm{~cm}$
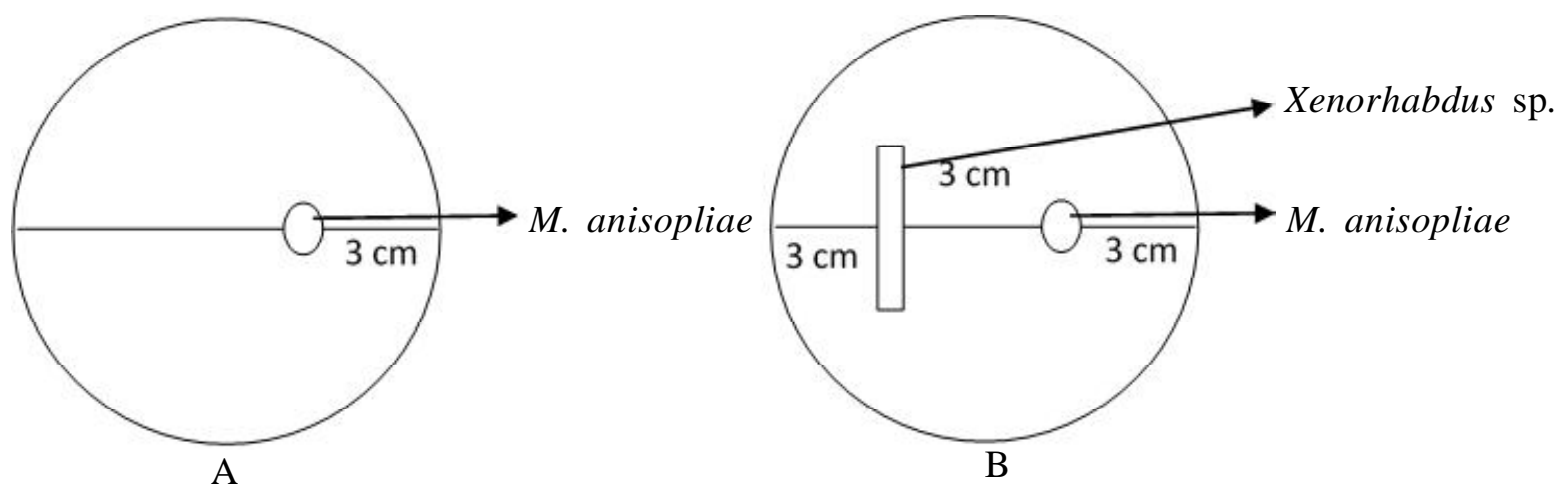

Gambar 1. Metode uji kompatibilitas secara in vitro; A. sketsa penumbuhan M. anisopliae secara tunggal; B. sketsa penumbuhan $M$. anisopliae secara tunggal. 
dari titik inokulasi bakteri Xenorhabdus sp. Bakteri Xenorhabdus sp. diambil dengan ose steril dan digoreskan secara garis pada jarak $3 \mathrm{~cm}$ dari tepi cawan Petri. Sebagai pembanding dilakukan inokulasi tunggal semua isolat $M$. anisopliae tanpa inokulasi bakteri simbion Xenorhabdus sp. pada jarak $3 \mathrm{~cm}$ dari tepi cawan Petri (Gambar 1). Pengamatan dilakukan interval 3 hari setelah investasi (HSI) dan dihentikan setelah miselium $M$. anisopliae yang ditumbuhkan secara tunggal menyentuh bagian tepi cawan Petri.

Persentase Hambatan Pertumbuhan M. anisopliae. Persentase hambatan dihitung dari panjang diameter $M$. anisopliae pada pengamatan terakhir menggunakan rumus persentase hambatan sebagai berikut:

$$
\mathrm{H} \%=\frac{\mathrm{d}_{1}-\mathrm{d}_{2}}{\mathrm{~d}_{1}} \times 100 \%
$$

dengan:

$\mathrm{H} \%$ = persentase daya hambat;

$\mathrm{d}_{1} \quad=$ diameter pertumbuhan $M$. anisopliae kontrol;

$\mathrm{d}_{2} \quad=$ diameter pertumbuhan M. anisopliae perlakuan.

Indeks Kompatibilitas. Variabel pengamatan menunjukkan reaksi kompatibilitas antara $M$. anisopliae dan Xenorhabdus sp. yang ditumbuhkan bersama dalam satu cawan Petri, apakah terjadi penghambatan pertumbuhan M. anisopliae oleh Xenorhabdus sp. atau tidak. Nilai indeks kompatibilitas (IK) dihitung berdasarkan rumus yang diadopsi dan dimodifikasi dari Hamilton \& Attia (1997).

Jika IK > 1= uji tersebut tidak kompatibel (antagonis) dan jika IK $1=$ uji tersebut kompatibel (sinergis).

Analisis Data. Hasil pengamatan uji reaksi kompatibilitas secara bioasssay dan hambatan pertumbuhan $M$. anisopliae pada uji kompatibilitas secara in vitro dianalisis ragam menggunakan ANOVA dengan bantuan software StatView versi 5.0.1 SAS (1998) dan data yang menunjukkan berbeda nyata diuji lanjut dengan uji Tukey pada taraf 5\%.

\section{HASIL DAN PEMBAHASAN}

Reaksi Kompatibilitas pada Uji Bioassay. Hasil analisis ragam kedua uji Bioassay menunjukkan bahwa perlakuan kombinasi antara $M$. anisopliae dengan Steinernema sp. terhadap mortalitas kenyataan $T$. molitor tidak nyata dengan $\mathrm{P}-\mathrm{Value}=0,0769$ untuk uji bioassay pertama, dan $\mathrm{P}-$ Value $=0,3116$ untuk uji bioassay kedua. Berdasarkan rasio nilai mortalitas kenyataan dengan mortalitas harapan pada uji Bioassay pertama pada 4 hari setelah infeksi $M$. anisopliae yaitu menunjukkan semua perlakuan terjadi interaksi antagonis (Tabel 1), demikian juga pada uji bioassay kedua pada 4 hari setelah infeksi Steinernema sp. (Tabel 2).

Hasil pengataman gejala infeksi T. molitor yang mati baik pada uji bioassay pertama maupun pada uji bioassay kedua menunjukkan tidak ada $M$. anisopliae yang berhasil tumbuh pada tubuh $T$. molitor sampai pengamatan 7 hari setelah perlakuan infeksi pertama. Gejala infeksi yang ditemukan hanya disebabkan oleh nematoda entomopatogen Steinernema sp. Hasil penelitian ini sesuai dengan hasil penelitian Alfarizi (2014), yaitu gejala Lepidiota stigma yang mati terinfeksi pada perlakuan kombinasi $M$. anisopliae dengan Steinernema sp. hanya disebabkan oleh nematoda entomopatogen Steinernema sp. Gejala infeksi nematoda Steinernema sp. yaitu terjadinya perubahan warna pada tubuh menjadi cokelat gelap. Chaerani et al. (2007) menyebutkan bahwa T. molitor yang terinfeksi Steinernema sp. menunjukkan gejala khas yaitu tubuh menjadi cokelat muda sampai cokelat gelap. Hal tersebut mengindikasikan bahwa $M$. anisopliae dengan Steinernema sp. bersifat antagonis sehingga M. anisopliae tidak mampu tumbuh pada tubuh $T$. molitor setelah nematoda menginfeksi tubuh $T$. molitor. Setelah tubuh serangga uji T. molitor dibedah, menunjukkan di dalam tubuh T. molitor terdapat nematoda entomopatogen Steinernema sp.. Hal ini menandakan Steinernema sp. berkembang dan hidup dalam tubuh $T$. molitor yang mati (Gambar 2). ShapiroIlan et al. (2004) menyatakan bahwa interaksi antagonis pada kombinasi nematoda entomopatogen dengan cendawan entomopatogen disebabkan oleh bakteri simbion yang dilepaskan oleh nematoda dalam tubuh serangga yang terinfeksi.

Bakteri Simbion Xenorhabdus sp. Hasil Isolasi. Isolat bakteri Xenorhabdus sp. yang digunakan pada uji kompatibilitas secara in vitro merupakan isolat yang diperoleh dari serangga terinfeksi nematoda entomopatogen Steinernema sp. Koloni bakteri Xenorhabdus sp. akan tumbuh seteleh diisolasi dari haemolymph serangga terinfeksi dan diinkubasi selama 24 jam pada ruang gelap dengan tanda koloni bakteri simbion Xenorhabdus sp. fase primer berwarna biru pada media NBTA (Gambar 3). Menurut Lengyel et al. (2005), bakteri X. budapestensis fase primer pada media indikator NBTA koloninya berwarna biru. 
Tabel 1. Reaksi kompatibilitas infeksi M. anisopliae dan Steinernema sp. 48 jam berikutnya pada T. molitor pada uji bioassay pertama

\begin{tabular}{lcccccccc}
\hline $\begin{array}{c}\text { Isolat } \\
\text { M. anisopliae }\end{array}$ & Spora/ml & Nematoda & $\mathrm{JI} / \mathrm{ml}$ & $\begin{array}{c}\text { Interval } \\
\text { aplikasi } \\
\text { (hari) }\end{array}$ & $\begin{array}{c}\text { Mo } \\
(\%)\end{array}$ & $\begin{array}{c}\text { Me } \\
(\%)\end{array}$ & $\mathrm{X}^{2}$ & Interaksi \\
\hline Jombang 1 & $10^{8}$ & Steinernema sp. & 200 & 2 & 92 & 95,7 & 0,14 & Antagonis \\
Jombang 2 & $10^{8}$ & Steinernema sp. & 200 & 2 & 98 & 99,3 & 0,02 & Antagonis \\
Kediri & $10^{8}$ & Steinernema sp. & 200 & 2 & 94 & 96,6 & 0,22 & Antagonis \\
Banyuwangi & $10^{8}$ & Steinernema sp. & 200 & 2 & 96 & 97,6 & 0,03 & Antagonis \\
Bondowoso & $10^{8}$ & Steinernema sp. & 200 & 2 & 88 & 92,8 & 0,25 & Antagonis \\
\hline
\end{tabular}

$\mathrm{JI}=$ Juvenil Infektif; $\mathrm{Mo}=$ Mortalitas kenyataan; $\mathrm{Me}=$ Mortalitas harapan yang dihitung berdasarkan rumus: $\mathrm{Mn}-\mathrm{Mi}$ (1-Mn/100). Untuk interaksi kompatibilitas dilihat berdasarkan rasio mortalitas kenyataan dengan mortalitas harapan pada $\mathrm{X}^{2}$.

Tabel 2. Reaksi kompatibilitas infeksi Steinernema sp.dan M. anisopliae 48 jam berikutnya pada T. molitor pada uji bioassay kedua

\begin{tabular}{lcccccccc}
\hline $\begin{array}{c}\text { Isolat } \\
\text { M. anisopliae }\end{array}$ & Spora/ $\mathrm{ml}$ & Nematoda & $\mathrm{JI} / \mathrm{ml}$ & $\begin{array}{c}\text { Interval } \\
\text { aplikasi } \\
\text { (hari) }\end{array}$ & $\begin{array}{c}\text { Mo } \\
(\%)\end{array}$ & $\begin{array}{c}\mathrm{Me} \\
(\%)\end{array}$ & $\mathrm{X}^{2}$ & Interaksi \\
\hline Jombang 1 & $10^{8}$ & Steinernema sp. & 200 & 2 & 98 & 100 & 0,04 & Antagonis \\
Jombang 2 & $10^{8}$ & Steinernema sp. & 200 & 2 & 98 & 100 & 0,04 & Antagonis \\
Kediri & $10^{8}$ & Steinernema sp. & 200 & 2 & 94 & 100 & 0,36 & Antagonis \\
Banyuwangi & $10^{8}$ & Steinernema sp. & 200 & 2 & 98 & 100 & 0,04 & Antagonis \\
Bondowoso & $10^{8}$ & Steinernema sp. & 200 & 2 & 96 & 100 & 0,16 & Antagonis \\
\hline
\end{tabular}

$\mathrm{JI}=$ Juvenil Infektif; $\mathrm{Mo}=$ Mortalitas kenyataan; $\mathrm{Me}=$ Mortalitas harapan yang dihitung berdasarkan rumus: $\mathrm{Mn}-\mathrm{Mi}$ (1-Mn/100). Untuk interaksi kompatibilitas dilihat berdasarkan rasio mortalitas kenyataan dengan mortalitas harapan pada $\mathrm{X}^{2}$.
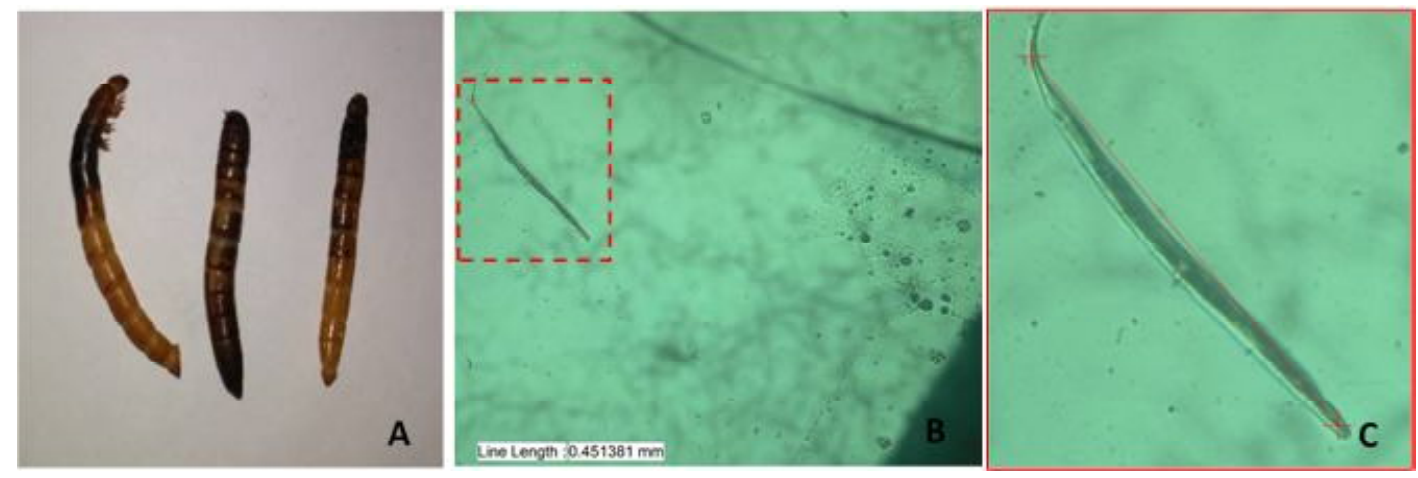

Gambar 2. Hasil identifikasi T. molitor mati terinfeksi; A. T. molitor terinfeksi nematoda Steinernema sp. dengan gejala tubuh serangga terinfeksi berwarna cokelat muda sampai cokelat tua, B. dan C. Pengamatan nematoda di bawah mikroskop dari tubuh T. molitor yang dibedah 

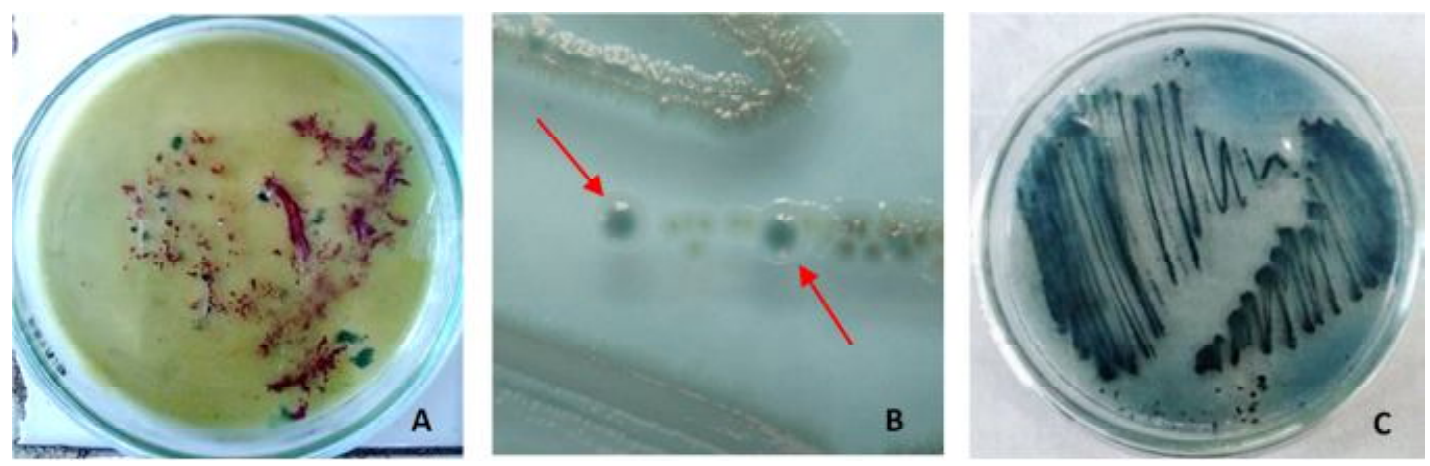

Gambar 3. Koloni bakteri simbion Xenorhabdus sp. hasil Isolasi; A. Koloni bakteri simbion Xenorhabdus sp. hasil isolasi, B. Koloni tunggal bakteri simbion Xenorhabdus sp. fase primer, C. Isolat bakteri Xeborhabdus sp. murni

Tabel 3. Persentase hambatan isolat $M$. anisopliae oleh bakteri simbion Xenorhabdus sp.

\begin{tabular}{lc}
\hline \multicolumn{1}{c}{ Perlakuan } & Rata-rata persentase daya hambat (\%) \\
\hline Met. Jombang 1 dan Xenorhabdus & 45,38 \\
Met. Jombang 2 dan Xenorhabdus & 38,12 \\
Met. Kediri dan Xenorhabdus & 41,54 \\
Met. Banyuwangi dan Xenorhabdus & 41,54 \\
Met. Bondowoso dan Xenorhabdus & 40,64 \\
\hline
\end{tabular}

Persentase Hambatan Pertumbuhan M. anisopliae. Uji kompatibilitas antara isolat cendawan M. anisopliae dan bakteri simbion Xenorhabdus sp. ini dilakukan untuk mengetahui kemampuan bakteri Xenorhabdus sp. menghambat pertumbuhan cendawan $M$. anisopliae. Hasil analisis ragam menunjukkan bahwa perlakuan asal isolat $M$. anisopliae tidak nyata mempengaruhi daya hambat bakteri simbion Xenorhabdus sp. dengan PValue $=0,0758$ (Tabel 3). Daya hambat bakteri Xenorhabdus sp. terhadap cendawan $M$. anisopliae pada uji kompatibilitas ini berkisar antara 38,1-45,5\%.

Pada pengamatan 9 hari setelah infestasi pada uji kompatibilitas secara in vitro diketahui bahwa bakteri simbion Xenorhabdus sp. mampu menghambat pertumbuhan semua isolat M. anisopliae (Gambar 4). Ansari et al. (2005) menyatakan bahwa bakteri simbion Xenorhabdus sp. mampu menghambat pertumbuhan cendawan entomopatogen. Menurut Dowds (1998), bakteri simbion Xenorhabdus sp. menghasilkan senyawa metabolit sekunder yang bersifat antimikotik. Dijelaskan oleh Li et al. (1995) bahwa senyawa antimikotik yang dihasilkan oleh bakteri simbion Xenorhabdus sp. yaitu indoles dan dithiolopyrrolones (xenorhabdins, xenomins, dan xenorxides). Senyawa antimikotik lainnya yang juga dihasilkan oleh bakteri Xenorhabdus sp. yaitu xenocoumacins, hydroxystilbenes, dan nucleosides (Webster et al., 2002).

Indeks Kompatibilitas Isolat $M$. anisopliae dengan Bakteri Simbion Xenorhabdus sp. Berdasarkan pengamatan indeks kompatibilitas antara M. anisopliae dengan bakteri simbion Xenorhabdus sp. menunjukkan bahwa semua isolat $M$. anisopliae yang diuji tidak kompatibel dengan bakteri simbion Xenorhabdus sp. Kriteria indeks kompatibilitas dikatakan tidak kompatibel atau antagonis jika nilai indeks kompatibilitas $>1$ dan dikatakan kompatibel atau sinergis jika nilai indeks kompatibilitas $\leq 1$ (Hamilton \& Attia, 1997; Hanudin et al., 2012). Nilai indeks kompatibilitas perlakuan dari semua isolat $M$. anisopliae uji dengan bakteri simbion Xenorhabdus sp. berturut-turut 1,9; 1,6; 1,7; 1,7 dan 1,7 sehingga dapat dikatakan kompatibilitas antara isolat M. anisopliae dengan bakteri simbion Xenorhabdus sp. bersifat antagonis (Tabel 4). 

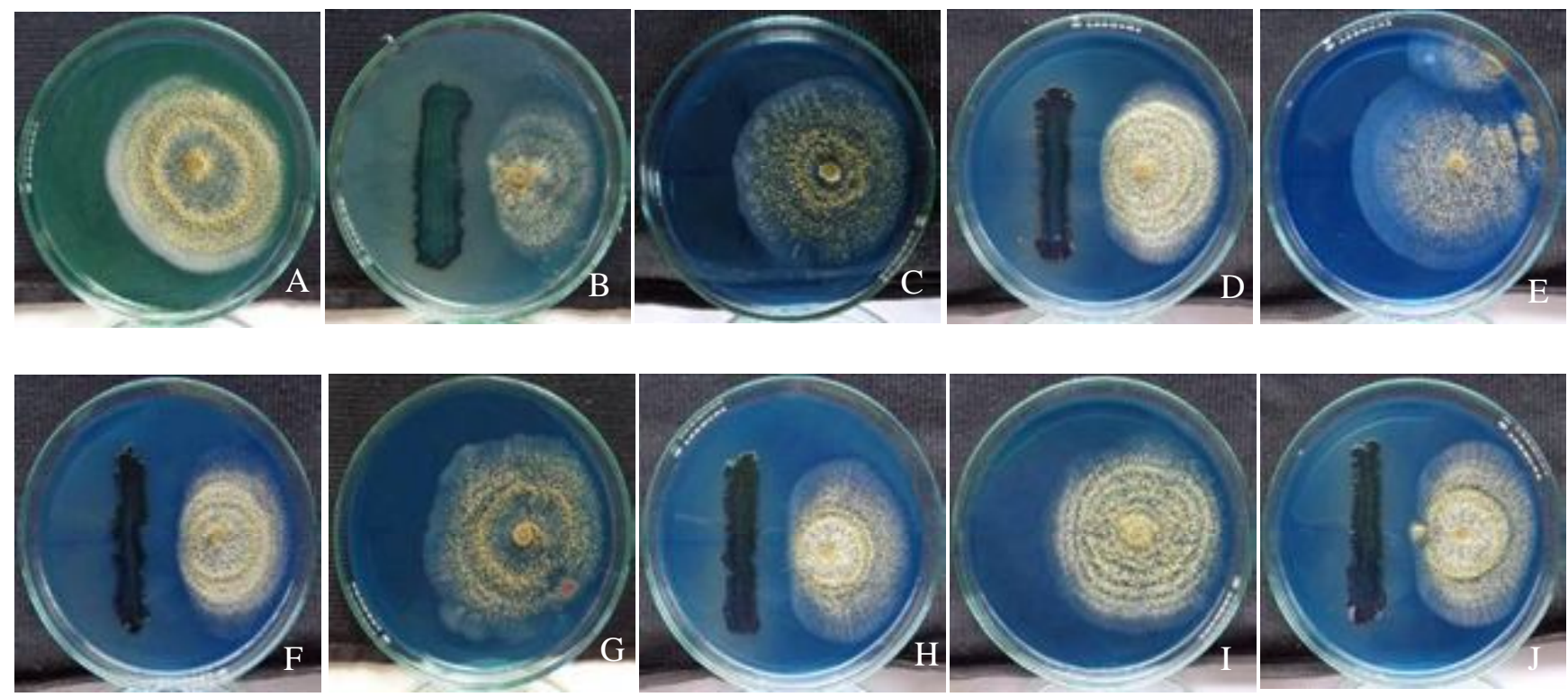

Gambar 4. Hasil uji kompatibilitas secara in vitro pada media NBTA; A. Jombang 1 kontrol, B. Jombang 1 dengan Xenorhabdus sp., C Jombang 2 kontrol, D. Jombang 2 dengan Xenorhabdus sp., E. Kediri kontrol, F. Kediri dengan Xenorhabdus sp., G. Banyuwangi kontrol, H. Banyuwangi dengan Xenorhabdus sp.; I. Bondowoso kontrol, J. Bandowoso dengan Xenorhabdus sp

Tabel 4. Indeks kompatibilitas isolat M. anisopliae dengan Xenorhabdus sp. secara in vitro

\begin{tabular}{lccc}
\hline \multicolumn{1}{c}{ Perlakuan } & Diameter Koloni $(\mathrm{cm})$ & Indeks Kompatibilitas (IK) & Keterangan \\
\hline Met Jombang 1 & 6,5 & - & - \\
Met Jombang $1 \times$ Xenorhabdus & 3,54 & 1,9 & Antagonis \\
Met Jombang 2 & 6,4 & - & - \\
Met Jombang $2 \times$ Xenorhabdus & 3,96 & 1,6 & Antagonis \\
Met Kediri & 6,5 & - & - \\
Met Kediri $\times$ Xenorhabdus & 3,8 & 1,7 & Antagonis \\
Met Banyuwangi & 6,5 & - & - \\
Met Banyuwangi $\times$ Xenorhabdus & 3,8 & 1,7 & Antagonis \\
Met Bondowoso & 6,3 & - & - \\
Met Bondowoso $\times$ Xenorhabdus & 3,74 & 1,7 & Antagonis \\
\hline
\end{tabular}

IK $>1=$ Uji tersebut tidak kompatibel (antagonis); IK $\leq 1=$ Uji tersebut kompatibel (sinergis).

\section{SIMPULAN}

Berdasarkan hasil penelitian dapat disimpulkan bahwa kompatibilitas antara cendawan $M$. anisopliae dengan nematoda Steinernema sp. bersifat antagonis, dan bakteri simbion nematoda entomopatogen Xenorhabdus sp. mampu menghambat pertumbuhan cendawan $M$. anisopliae.

\section{SANWACANA}

Penulis mengucapkan terima kasih kepada Lembaga Penelitian Universitas Jember dengan Skim Usaha Strategi Nasional atas dana hibah penelitian yang diberikan tahun anggaran 2016 Nomor: 187B/UN25.3.1/ LT/2016. 


\section{DAFTAR PUSTAKA}

Alfarizi S. 2014. Pengendalian hayati uret menggunakan nematoda patogen serangga (nps) dan Metarhizium sp. di laboratorium. Skripsi. Universitas Jember. Jember.

Ansari MA, Shah FA, \& Butt TM. 2008. Combined use of entomopathogenic nematodes and Metarhizium anisopliae as a new approach for black vine weevil, Otiorhynchus sulcatus, control. Entomol. Exp. Appl. 129(3): 340-347.

Ansari MA, Tirry L, \& Moens M. 2005. Antagonism between entomopathogenic fungi and bacterial symbionts of entomopathogenic nematodes. Biocontrol 50(3): 465-475.

Chaerani, Suryadi Y, Priyatno TP, Koswanudin D, Rahmat U, Sujatmo, Yusuf, \& Griffin CT. 2007. Isolasi nematoda patogen serangga Steinernema dan Heterorhabditis. J. HPT Tropika 7(1): 1-9.

Dowds B. 1998. Bacterial virulence mechanism. In: Simões N, Boemare N, \& Ehlers RU (Eds). Entomopathogenic Nematodes. Pp. 9-19. European Commission, Luxembourg.

Farenhorst M, Knols BGJ, Thomas MB, Howard AFV, Takken W, Rowland M, \& N'Guessan R. 2010. Synergy in efficacy of fungal entomopathogens and permethrin against west African insecticideresistant Anopheles gambiae mosquitoes. Plos One 5(8): 1-10.

Hamilton JT \& Attia FL. 1997. Effect of mixture of Bacillus thuringiensis and pesticide on Plutella xylostella and the parasite Thyraella collaris. J. Econ. Entomol. 70(1): 146-148.

Hanudin B, Marwanto, Hersanti, \& Muharam A. 2012. Kompatibilitas Bacillus subtilis, Pseudomonas fluorecens, dan Trichoderma harzianum untuk mengendalikan Ralstonia solanacearum pada tanaman kentang. J. Hort. 22(2): 172-179.
Hartati S. 2013. Pengendalian Hama Uret pada Tanaman Tebu. http://www.puslitgula10.com/ 2013/05/pengendalian-hama-uret-padatanaman-tebu_16.html. Diakses tanggal 10 Januari 2017.

Lengyel K, Elke L, Andra’s F, Emilia S, Peter S, \& Erko S. 2005. Description of four novel species of Xenorhabdus, family Enterobacteriaceae: Xenorhabdus budapestensis sp. nov., Xenorhabdus ehlersii sp. nov., Xenorhabdus innexi sp. nov., and Xenorhabdus szentirmaii sp. nov. Syst. Appl. Microbiol. 28(2): 115-122.

Li J, Chen G, Webster JM, \& Czyzewska E. 1995. Antimicrobial metabolites from a bacterial symbiont. J. Nat. Prod. 58(7): 1081-1086.

SAS 1998. Using Statview. SAS Institute Inc., USA.

Shapiro-Ilan DI, Jackson M, Reilly CC, \& Hotchkiss MW. 2004. Effects of combining on entomopathogenic fungi or bacterium with entomopathogenic nematodes on mortality of Curculio caryae (Coleoptera: Curculionidae). J. Biol. Control 30(1): 119-126.

Trizelia, Syam U, \& Herawaty Y. 2010. Virulensi isolat Metarhizium sp. yang berasal dari beberapa rizosfer tanaman terhadap Crocidolomia pavonana Fabricus (Lepidoptera: Pyralidae). Manggrove 10(2): 51-59.

Webster JM, Chen G, Kaiji-Hu, \& Jianxiong-li. 2002. Bacterial metabolites. In: Gaugler R (Ed.). Entomopathogenic Nematology. Pp. 99-114. Cabi Publishing, New York USA.

Xu XM, Jeffries P, Pautasso M, \& Jeger MJ. 2011. Combined use of biocontrol agents to manage plant diseases in theory and practice. $J$. Phytopathology 101(9): 1024-1031. 